\title{
How Does Online Engagement Drive Consumers' Webrooming Intention? A Moderated-Mediation Approach
}

\author{
Amit Shankar, Indian Institute of Management, Visakhapatnam, India \\ Rambalak Yadav, Institute of Management Technology, Hyderabad, India \\ Manish Gupta, ICFAI Business School, Hyderabad, India \\ (iD) https://orcid.org/0000-0001-9671-1605 \\ Charles Jebarajakirthy, Griffith Business School, Griffith University, Australia
}

\begin{abstract}
Based on the cognitive-motivational-relational (CMR) theory, this study empirically investigates the mechanisms through which consumers' online engagement impacts their channel switching intention. The present study examines the mediating effects of perceived value and the ways in which these mediating effects are moderated by online risk perception. Data were collected from 428 online Indian consumers using systematic random sampling. The results of the structural and process macro analyses indicated that consumer online engagement has a significant impact on consumer online search benefits which in turn leads to webrooming intention. Also, perceived value mediated the effects of online search benefits and offline purchase benefits on webrooming intention. The results advance the theory of CMR by explaining consumer channel switching behaviour and are expected to help multi-channel retailers to identify the key drivers that help engage consumers online.
\end{abstract}

\section{KEYWORDS}

Multi-Channel Retailing, Online Engagement, Online Risk Perception, Perceived Value, Webrooming Intention

\section{INTRODUCTION}

Due to widespread access to the internet, increasing mobile phone penetration, and developed information systems, channel switching behaviour has become a common phenomenon (Arora \& Sahney, 2018; Verhoef et al., 2007). Webrooming has emerged as a frequent consumer behaviour relating to channel selection where consumers search information over online platforms before making a final purchase from offline stores (Frasquet et al., 2015; Flavián et al., 2016; Fernández et al., 2018; Wong et al., 2018; Aw, 2019; Flavián et al., 2020; Shankar \& Jain, 2020). According to a Price waterhouse Coopers' $(\mathrm{PwC}$ ) recent report, a large number of consumers visit a company's website to collect information before purchasing a product or availing of services from the company's offline store (PwC, 2015). According to the Deloitte (2017) report, more than 69\% of consumers search for products and services online before purchasing them offline. Further, more than $72 \%$ of The United States of America (USA) consumers search for product information over online platforms before purchasing from physical stores (D’Avanzo \& Pilato, 2015). The majority of the purchases at

DOI: 10.4018/JGIM.20211101.oa19

This article published as an Open Access article distributed under the terms of the Creative Commons Attribution License (http://creativecommons.org/licenses/by/4.0/) which permits unrestricted use, distribution, and production in any medium, provided the author of the original work and original publication source are properly credited. 
physical stores is the outcome of the consumers' web activities (Flavián et al., 2016). Due to separate accounting books for online and offline channels and webrooming behaviour, marketers are facing massive channel conflict (Aw, 2020). Nevertheless, scholars argue that consumers who are active on different online platforms, perceive several search benefits motivate consumers to search the information about product and services over online platforms (Frasquet et al., 2015). Additionally, in recent times, digital technologies metaphorically change consumer engagement, a psychological state of mind to interact frequently with a brand or a medium, with marketers from offline to online medium (Harmeling et al., 2017; Brodie et al., 2019; Ferreira et al., 2020; Thakur, 2018). Now a day, consumer engagement with online platforms play a crucial role in forming consumer behavioural intention (Morgan-Thomas et al., 2020). Consumer online engagement is the outcome of several hedonic, emotional, social, and utilitarian values that consumers receive over online platforms (Mazaheri et al., 2010; Park et al., 2012; Mehra et al., 2013).

The consumer engagement literature is a well-explored phenomenon, and the majority of the studies examine the antecedents and outcome of consumer engagement with a specific brand (Carvalho \& Fernandes, 2018; Gong, 2018), service provides (Verleye et al., 2014; Meshram \& O'Cass, 2018), and specific firm (Kumar \& Pansari, 2016; Harmeling et al., 2017). However, scant efforts were made in the literature to explore the impact of consumer engagement with online mediums $(\mathrm{Ng}$ et al., 2020). This study attempts to fill the above gap by examining how consumer engagement with online platforms play a role in shaping consumer behavioural intention. Further, Emerging research suggested that consumer online engagement leads to several positive consumer responses such as purchase intention, trust, satisfaction, loyalty, commitment, repurchase intention, forgiveness, and positive word of mouth (Fernandes \& Esteves, 2016; Ahn \& Back, 2018; Thakur, 2018; Kharouf, et al., 2020; Ng et al., 2020; Yuan et al., 2020). However, very scant efforts were made to examine the negative impact of consumer engagement on consumer behavioural intention ( $\mathrm{Ng}$ et al., 2020). This is the gap in the literature and the study attempts to fill the above gap by examining the impact of consumer online engagement on channel switching behaviour.

Further, consumer webrooming behaviour is one of the crucial changes faced by multi-channel retailer hence, in the literature, attempts were made to explore factors affecting webrooming behaviour (Flavián et al., 2016; Fernández et al., 2018; Arora \& Sahney, 2019; Aw, 2019, 2020). Consumer engagement in specific channels plays a crucial role in enhancing consumer experience and consumer channel selection for purchasing a product or availing of services (Shankar et al., 2020). Similarly, consumer engagement towards online platforms motivates consumers to search the product online before purchasing it offline which is a key issue for retailers. Hence, retailers are keen to know how consumer engagement towards online platforms affects consumer webrooming intention. But, no study examined the role of consumer engagement in forming webrooming intention. However, consumers who are engaged over online planforms tend to search for information online before making final purchase offline. Hence, it is crucial to examine the role of consumer engagement on webrooming intention. This indicates a dearth of literature in this area and a lack of understanding of webrooming intention. Hence, the purpose of this study is to examine the impact of consumer engagement on webrooming intention by proposing a moderated mediation framework. The study investigates how consumer's online engagement enhances online search benefits, which leads to webrooming intention. The impact of consumer engagement on consumer webrooming intention is not straightforward; hence, the study examines the mechanism using perceived value as a mediator. The study also examines how online risk perception moderates the mediating effect of perceived value.

This research carries several academic and practical significance. In terms of its academic significance, this research first enriches consumer engagement literature by examining the negative impact of consumer engagement on consumer channel switching behaviour. Further, this study also enriches the emerging webrooming literature. Further research also enriches consumer perceived value literature. Finally, by applying the cognitive-motivational-relational (CMR) theory to explain the effects of consumer engagement on webrooming intention, this study extends the CMR theory 
in the channel switching behaviour literature. Overall, this study contributes to the CMR theory and consumer behaviour literature, particularly consumer engagement and consumer channel switching behaviour literature.

The remaining paper has been organised as follows: It starts with the review of literature and consequently develops the relevant hypotheses for the study. In the next section, it provides the research method adopted for the study, and then the data analysis results. Next, it discusses the results obtained and provides some of the key academic and practical implications of the study. It then discusses some of the limitations of this study and future research directions.

\section{LITERATURE REVIEW}

\subsection{Webrooming Intention}

Due to information technology advancement and increased penetration of the internet and mobile phones, retailers tend to adopt multichannel retailing strategy to deliver products and services to consumers (Goworek \& McGoldrick 2015). Due to multichannel strategy consumer can enhance the reachability among consumers and gain competitive advantages but, along with above benefits, consumer channel switching behaviour emerges as a crucial challenge (Verhoef et al., 2007; Kalyanam \& Tsay, 2013; Fernández et al., 2018; Arora \& Sahney, 2019; Aw, 2020; Flavián et al., 2020). Consumers switch channels during the purchase process to take the advantage of all available channels (Flavián et al., 2016). Consumer channel switching behaviour during the purchasing process results in the emergence of "showrooming" and "webrooming" phenomena.

When consumers search for information over online platforms and purchase products or avail services at a physical store, it is known as webrooming (Wong et al., 2018; Arora \& Sahney, 2019; Aw, 2020; Shankar and Jain, 2020). However, in showrooming, customers deliberately visit the physical stores to gather product details before purchasing them online (Goworek \& McGoldrick 2015; Flavián et al., 2016). In the recent past, consumer webrooming intention was found to be a crucial challenge, and retailers are keen to know how they can manage consumer webrooming behaviour. In the webrooming context, consumers tend to visit online platforms to collect product information before making a final purchase from an offline store (Flavián et al., 2016; Shankar and Jain, 2020).

The cognitive-motivational-relational (CMR) theory proposed by Lazarus (1991) has been used to provide theoretical support for examining the impact of consumer engagement on consumers' webrooming intentions. The CMR theory is based on the association between cognitive evaluation and emotional response of the consumers. Consumers evaluate their surrounding cues based on their values, beliefs, and objectives and respond to those cues accordingly. In the Information Systems literature, CMR theory is extensively used in exploring consumers' responses to environmental cues (Nicholls et al., 2012; Shankar \& Jebarajakirthy, 2019). In this study, consumers evaluate online search benefits based on their online engagement level and accordingly represent webrooming intention as a response.

\section{HYPOTHESES DEVELOPMENT}

\subsection{Online Search Benefits and Webrooming Intention}

Over online platforms, consumers can access a huge amount of information about the product in a few clicks only (Islam et al., 2019). Hence, consumers prefer to search for information over online platforms to reduce performance uncertainty and future guilt (Arora \& Sahney, 2019). Consumers receive several information search benefits such as access to online reviews, better assortment, and lower search cost over online platforms. Hence, consumers tend to visit online platforms to explore products before making final purchase decisions (Aw, 2020). 


\subsubsection{Access to Online Reviews and Webrooming Intention}

The online review refers to "information share by potential, actual, or former customers about a product or company over online platforms which is publicly available" (Hennig-Thurau et al., 2004, p. 39). Online reviews provide information about product functionality (Cui et al., 2012), which reduces the uncertainties about product performance (Flavián et al., 2016; Shankar et al., 2020). Hence, consumers visit different online platforms to collect information about the product, enabling them to make an informed purchase decision (Lee \& Ma, 2012). Further, consumers also interact with existing consumers who had shared reviews to get more information about product performance (Flavián et al., 2016; Aw, 2020). Consumers found online reviews more trustworthy compare to information shared by marketers because reviews are shared by existing users (Santos \& Gonçalves, 2019; Shankar et al., 2020). Online reviews help consumers understand the functions and features of the product and provide a detailed comparison with different brands that reduce performance uncertainty (Zhang et al., 2014; Flavian et al., 2016; Aw, 2020). Thus, access to online reviews can be the causal condition of consumers' webrooming intention. Hence, we propose the following hypothesis;

\section{$H_{1}:$ Access to online reviews positively influences webrooming intention.}

\subsubsection{Better Assortment and Webrooming Intention}

Product assortment refers to "the availability of a variety of merchandise in terms of quality, quantity, and brand choice" (Verhoef et al., 2007). Due to space constraints in a brick-and-mortar setting, retailers have limited opportunities to showcase the product verities; however, over online platforms, retailers can showcase a wide range of product verity (Kang, 2018; Goraya et al., 2020). Online retailers can also use online catalog to feature breadth and depth of products and services (Islam et al., 2019). Moreover, online shoppers can show a wide variety of products in terms of color, size, and design (Kang, 2018). Apart from that, online retailers can show similar brands of a product as well as a complementary product to enhance customers' choice (Goraya et al., 2020). Product assortment plays a crucial role in consumer channel choice during the purchasing process (Verhoef et al., 2015; Gensler et al., 2017). Over online platforms, consumers receive better assortment and save time, money, and efforts in the evaluation of the products (Rubio et al., 2017; Shankar and Jain, 2020) but also get the automatic suggestions of complementary, bundling, and substitute products, which help them in better evaluation (Kang, 2018; Goraya et al., 2020). Over online platforms, consumers can quickly gather comparative information regarding features, price, quality, warranty, and consumer ratings of alternative products and brands (Duarte et al., 2018; Shankar et al., 2020), which is difficult to obtain in offline stores. Accordingly, we hypothesize the following;

\section{$\mathrm{H}_{2}$ : Better assortment positively influences webrooming intention.}

\subsubsection{Lower Search Cost and Webrooming Intention}

Search cost refers to time, money, and efforts required to search for information about products or services (Noble et al., 2005). Online platforms provide a vast amount of information on products and enable customers to access information at lower cost compared to offline stores (Carlton \& Chevalier, 2001). If they need to access product information from brick-and-mortar stores, they need to physically visit the stores, which incurs costs to customers and requires time and effort (Jepsen, 2007). Online platforms provide a comprehensive infrastructure that helps consumers in collecting and comparing a huge amount of data in a convenient manner (Maheswarappa et al., 2017; Jebarajakirthy \& Shankar, 2020). Whereas, consumers can receive limited information in an offline setting, and they have to visit different offline stores to collect information which requires a vast amount of resources. Hence, consumers prefer online platforms to search the information (Arora \& Sahney, 2018; Shankar and Jain, 
2020). Online platforms enable gathering an enormous amount of product information economically (Arora \& Sahney, 2019) as consumers can access a huge amount of information in a few clicks. Lower cost of accessing information online promotes online free-riding behaviour among consumers, and they tend to search online before making a final purchase decision. Hence, we hypothesize the following;

\section{$H_{3}:$ Lower search cost positively influences webrooming intention.}

\subsection{Consumer Engagement and Online Search Benefits}

Consumer engagement refers to "a psychological state that occurs by virtue of interactive, co-creative customer experiences with a focal object in focal service relationships" (Brodie et al., 2011, p. 260). Consumer engagement means frequent interaction of consumers with a specific object (Thakur, 2018). Consumer engagement has matured over the last decade; still there is not any consensus on the operationalization of consumer engagement (Thakur, 2018; $\mathrm{Ng}$ et al., 2020). In the existing literature, several attempts were made to examine the antecedents and outcomes of consumer engagement. The studies explored different attitudinal factors such as trust, commitment, satisfaction, and situation factors such as, service convenience and perceived service fairness, which lead to consumer engagement (Wirtz et al., 2013; Kumar \& Kumar, 2020; Yuan et al., 2020).

Studies also explored several outcomes of consumer engagement including purchase intention, trust, loyalty, satisfaction, word-of-mouth, and value co-creation (Brodie et al., 2011; Thakur, 2018; Kharouf, et al., 2020; Kumar \& Kumar, 2020; Ng et al., 2020; Yuan, et al., 2020). Recently, due to information technology advancement and the emergence of different social media platforms, consumers engage with marketers via online channel hence, consumer online engagement emerges as an attractive arena of research (Dessart et al., 2016; Hollebeek et al., 2019; Ng et al., 2020). The emergence of new technologies provided consumers several mediums to contact marketers such as, website, mobile applications, and social media platforms (Li et al., 2017). As online consumer engagement is different from offline consumer engagement ( $\mathrm{Ng}$ et al., 2020). Hence, studies examined the digital consumer engagement from different perspectives such as engagement via online brand communities (Gong, 2018; Chahal et al., 2020), engagement via mobile application (Marino \& Lo Pesti, 2018) and engagement through social media platforms (Wang and Lee, 2020). Although several studies explored consumer engagement in the extent literature, digital consumer engagement is still at the nascent stage and rarely studies the negative impact of online consumer engagement on consumer behavioural intention.

Consumers having high online engagement tend to perceive several online search benefits which include easy access to huge information, aces to the reviews shared by consumers, better assortment facilities, lower search cost and perceived usefulness of online information (Arora \& Sahney, 2018; Kang 2018; Aw, 2020). Consumers who are active on different online platforms, perceived several search benefits motivate consumers to search information about product and services over online platforms (Frasquet et al., 2015). Due to the increasing penetration of internet, consumers prefer to search information about products over different online platform prior to making purchase decision (Wang et al., 2018; Shankar et al., 2020). Compared to brick-and-mortar stores, over online platforms; consumers can gather a wider range of product information, which helps consumers to make a wellinformed purchase decision (Maheswarappa et al., 2017; Arora \& Sahney, 2018; Aw, 2020). Consumers who are engaged over different online platforms prefer to compare the features, performance, and price of alternative products and brands for making a rational purchase decision (Kang, 2018). Consumers can receive several search benefits by engaging over different online platforms, including access to online reviews, better assortment, and lower online information search cost, which might have a significant impact on consumers' webrooming intention.

Over online platforms, consumers are not only accessing the information shared by marketers but also access the information shared by existing users (Shankar et al., 2020). Consumers who 
are active on online platforms not only analyze the reviews shared by consumers but also engage in sharing the reviews and contacting existing users to get information about product performance (Zhang et al., 2014).

Due to space limitations, marketers can showcase a limited variety of products in an offline retail setting. Whereas, over online platforms, retailers can showcase a wide range of merchandise (Kang, 2018). Consumer, who engage over online platform can explore several designs, size, and color of particular products which help them in evaluating different available options. Further, active online users can compare the performance of different brands of a specific product category only in few clicks (Verhoef et al., 2007; Shankar et al., 2020a). Consumers can also compare the price of specific products over different online platforms for making a better purchase decision (Arora \& Sahney, 2019). Consumers can also explore substitute and complementary products over online platforms (Heitz-Spahn, 2013). Overall, the online platform provides a wide variety of merchandise, which encourages consumers to search for information online.

Searching information about product and services in offline is a costly affair which requires time, cost, and efforts (Shankar \& Rishi, 2020). However, over online platforms, consumers can access huge amounts of information in a few clicks only (Jiang et al., 2013). Consumers who are active on online platforms do not visit the offline stores to collect the information about products and services; they collect information by visiting different online platforms in convenient manner (Maheswarappa et al., 2017) because they are aware of different online platforms where they can collect relevant information about specific product. Hence, we propose the following hypotheses;

\section{$\mathrm{H}_{4}:$ Consumer online engagement leads to access to online reviews. \\ $\boldsymbol{H}_{5}:$ Consumer online engagement leads to the better assortment. \\ $\boldsymbol{H}_{\mathbf{6}}$ : Consumer online engagement leads to lower search costs.}

\subsection{Offline Purchase Benefits and Webrooming Intention}

Due to several perceive risk associated with online purchase, consumers prefer to purchase from offline stores (Shankar \& Datta, 2018). There is an absence of face-to-face interaction between sellers and buyers over the online platform, which develops a sense of uncertainty towards online purchase (Ha \& Stoel, 2009). Consumers can physically examine products during offline shopping, which reduces the uncertainty associated with the purchase (Arora \& Sahney, 2019). Online shopping also involves privacy and security risks. Consumers are afraid that their personal and financial information might be misused over online platforms (Shankar \& Kumari, 2016). Hence, they prefer to purchase offline over online platforms. Consumers perceive several benefits during offline purchase, including uncertainty reduction, touch and feel the experience, socialization, immediate possession, and personal interaction with salespeople. These benefits might drive consumers' webrooming intentions. Hence, we propose the following hypothesis;

\subsubsection{Touch and Feel Experience and Webrooming Intention}

Touch and feel experience with the product is another major motivation for purchasing products from offline stores (Mehra et al., 2013). In online purchase contexts, customers do not have an opportunity to touch and feel products, and hence they have uncertainty with product attributes, such as, quality, color, size and materials (i.e., ingredients used in products) (Peck \& Childers, 2006; Aw, 2020). However, while purchasing from brick-and-mortar stores, consumers can physically examine product attributes, which give them confidence about product attributes and product performance (Peck \& Childers, 2006; Arora \& Sahney, 2019). Sometimes the product which looks suitable due to interactivity of the website, consumer are not very much satisfied after getting it which leads to purchase regret (Flavian et al., 2016, Aw, 2020). Hence, customers prefer buying products via offline 
channels over the online channel, which drives their webrooming intention. Accordingly, we propose the following hypothesis;

$\boldsymbol{H}_{7}:$ Touch and feel motive positively influences webrooming intention.

\subsubsection{Socialization and Webrooming Intention}

An opportunity to interact with friends and family members is one of the major motivations for consumers' offline purchase (Rohm and Swaminathan, 2004). Consumers expect socialization benefits during shopping, such as spending some quality time with friends and family members. Consumers also seek their suggestions and advice, which helps them make their purchase decisions (Arora \& Sahney, 2018). However, consumers miss these socialization benefits during online shopping (Albesa, 2007; Shankar \& Jain, 2020). Further, consumers can spend some quality time with their family and friends in the gaming zone and entertainment section at physical stores (Wang et al., 2015). Consumers can also avail of the dining facility with their family members and friends at physical stores during the purchase, which is absence in online shopping (Arora \& Sahney, 2019). During offline shopping, consumers also tend to spend some time at the mall in recreation activities (Rohm \& Swaminathan, 2004). These socialization motives drive customers to purchase offline after searching for products online, thereby triggering webrooming intention. Hence, we propose the following hypothesis;

\section{$\boldsymbol{H}_{\mathbf{8}}$ : Socialisation positively influences webrooming intention.}

\subsubsection{Immediate Possession and Webrooming Intention}

Consumers have the opportunity to possess products immediately while purchasing from brick and mortar stores; however, in the online purchase context, there is a time gap between buying products and possessing those products (Noble et al., 2005). Sometimes, customers need products on an urgent basis, for example, products required for daily usage (i.e., grocery items) for which they need immediate possession (Park et al., 2012; Barbopoulos \& Johansson, 2016). In such circumstances, they need to purchase from physical stores. Consumers are also uncertain about product delivery time and product performance when purchasing online (Chou et al., 2016). Immediate passion also reduces the uncertainty associated with the delay in product delivery (Aw, 2019). The need for immediate possession drives people to search for products online and purchase them via physical stores; hence we propose the following;

\section{$\boldsymbol{H}_{\mathbf{9}}$ : Immediate possession motives positively influence webrooming intention.}

\subsubsection{Sales-Staff Assistance and Webrooming Intention}

The absence of face to face interaction with salespeople is a major limitation of online shopping (Kacen et al., 2013; Shankar and Rishi, 2020). Customers expect an interaction with salespeople to obtain after-sales service as well as information on the attributes, price, and performance of the products (Chiu et al., 2011). Consumers trust the information shared by salespeople about product attributes and product performance (Haas \& Kenning, 2014; Shankar et al., 2020). Customers also expect an interaction with and assistance of salespeople in case they encounter any problems during the purchasing process (Arora \& Sahney, 2019). In the online purchase context, customers hardly interact with salespeople or receive their immediate support (Collier et al., 2015). While purchasing from brick and mortar stores, customers have the opportunity to interact with salespeople and receive their immediate support and required information. As a result, customers research for products online and purchase them offline. Hence, we propose the following hypothesis; 
$\boldsymbol{H}_{\mathbf{1 0}}$ : Sales-staff assistance positively influences webrooming intention

\subsection{Mediating Role of Perceived Value in the Relationship between Online Search Benefits and Webrooming Intention}

The perceived value is the trade-off between perceived cost and perceived benefits during product purchase (Lee et al., 2007). Consumers do several searches before making the final purchase decision and received several perceived value during this process. These perceived value could be divided into two categories; hedonic values and utilitarian values (Park et al., 2012; Shankar \& Jain, 2020). During information search over the online platforms, consumers receive fun, and enjoyment (Mazaheri et al., 2010; Park et al., 2012; Shankar et al., 2019). Consumers receive pleasure in seeking information about a wide range of products regardless they are making a purchase or not (Smith and Sivakumar, 2004; Jebarajakirthy \& Shankar, 2020). The aesthetics of the website, audio-visual elements, interactive features, videos are the several cues that enhance consumers' hedonic values during online information search (Kim et al., 2008; Islam et al., 2019). The online information search is also providing several utilitarian values to the consumers (Park et al., 2012; Jebarajakirthy et al., 2020). Over online platforms, consumers can compare the price of the different products in a few clicks, which helps them make wise purchase decisions (Lee et al., 2009; Shankar \& Datta, 2019). Consumers can also compare the products of different brands in a specific product category, which may help consumers compare the brands (Park et al., 2012). The huge amount of information also reduces consumers' perceived risks and perceived future regret (Park \& Stoel, 2002; Shankar \& Jain, 2020). Further, online information provides several sensory cues such as design, colour, size, and fit about different products that provide utilitarian values to the consumers. Above all, online information search reduces consumers' time, efforts, and resources for getting information about specific products that offer utilitarian values to the consumers leading to enhanced purchase intention.

$\boldsymbol{H}_{11}:$ Perceived value mediated the relationship between $(a)$ access to online reviews $(b)$ better assortment (c) lower search cost and webrooming intention.

\subsection{Mediating Role of Perceived Value in the Relationship Between Offline Purchase Benefits and Webrooming Intention}

Consumers receive several hedonic and utilitarian values during offline purchases. During purchasing from physical retail stores, they also get the opportunity to socialize with family and friends (Rohm $\&$ Swaminathan, 2004). Nowadays, retailers provide several recreational and entertainment activities inside shopping premises where consumers can spend some quality time with family, friends, and relatives (Arora \& Sahney, 2018). Besides recreational facilities, retailers provide food court facilities where customers can enjoy food and beverages with family, friends, and relatives (Rohm \& Swaminathan, 2004; Shankar \& Jain, 2020). Apart from the above hedonic benefits, consumers are enjoying bargain hunting during the offline purchase, which enhances their perceived hedonic values.

Consumers prefer in-store purchasing to reduce risks and uncertainties associated with the purchase. Consumers want to receive touch and feel the experience to minimize the uncertainties (Mehra et al., 2013). Consumers feel a sense of certainty about product attributes hence prefer to purchase products offline (Peck \& Childers, 2006; Jebarajakirthy \& Shankar, 2020). Further, if consumers are buying products from physical stores, they get immediate possession of the product; however, in online purchases, they can't receive the products immediately (Barbopoulos \& Johansson, 2016). During the purchase from physical stores, consumers also get the salesperson assistance in product evaluation and selecting the best alternative products (Kacen et al., 2013; Arora \& Sahney, 2018), which enhances their perceived value, and they may perform webrooming. 
$\boldsymbol{H}_{12}$ : Perceived value mediated the relationship between (a) touch and feel experience (b) socialisation (c) immediate possession and (d) Personal interaction with salespeople and webrooming intention.

\subsection{Moderating Role of Online Risk Perception}

Due to the absence of face-to-face interaction over online platforms among consumers tend to avoid making online purchases (Shankar et al., 2020). Perceived online risks are the major hindrances in selecting an online channel for making final purchases (Lin et al., 2009; Jebarajakirthy \& Shankar, 2020). In previous literature, online risks found to be a crucial issue in online retailing contexts (Shankar \& Kumari, 2016). Due to high perceived risks over the online platform, the growth of online purchases is not as expected (Chen and He, 2003), and customers are still vulnerable towards the online purchase (Chou et al., 2016). Hence, to reduce the uncertainties associated with online purchasing, consumers prefer to purchase the products from physical stores (Forsythe et al., 2006; Shankar \& Jain, 2020). If consumers have a high perceived concern, they have more fear of receiving mismatched products, and they are uncertain about the quality of the products hence, perform webrooming activities (Chou et al., 2016). Whereas consumer who has less perceived privacy and security concern may purchase the products from online stores also and tend to avoid webrooming behaviour (Arora \& Sahney, 2019).

Further, consumers who are afraid of misusing their personal and financial information over online platforms tend to show webrooming behaviour (Frasquet et al., 2015). Whereas consumers who perceived less privacy and security concern feel safe in performing transactions over online platform, hence they represent less webrooming behaviour (Frasquet et al., 2015). Furthermore, consumers with high perceived online risks develop distrust towards online platforms and tend to purchase the products from physical stores (Ahmad and Sun, 2018). Whereas, consumers who have less perceived risks trust online marketers and avoid webrooming behaviour. All the hypothesized relationships are diagrammatically shown in Figure 1.

$H_{13}:$ Online risk perception significantly moderate the mediating impact of perceived value on the association between (a) access to online reviews (b) better assortment (c) lower search cost and webrooming intention.

$H_{14}$ : Online risk perception significantly moderate the mediating impact of perceived value on the association between (a) touch and feel experience $(b)$ socialisation $(c)$ immediate possession $(d)$ sales-staff assistance and webrooming intention.

\section{RESEARCH METHODS}

\subsection{Sample Characteristics and Procedure}

Responses were collected from using a structured questionnaire by visiting malls of four major cities including Delhi, Hyderabad, Kolkata, and Mumbai and their suburban areas which represent Northern, Southern, Eastern and Western regions respectively in India. Two malls from each of the cities were selected randomly from each city and a total of 100 respondents were approached at every mall to fill the responses. A total of 463 responses were received out of which 428 were found to be usable (completed fully). We have estimated the sample size using formula; $\mathrm{z}^{2 *} \mathrm{p} * \mathrm{q} / \mathrm{e}^{2}$ with $95 \%$ confidence interval and 5\% margin of error and 385 obtained as ideal sample size. Hence, study sample size is adequate for examining the hypothesis.

The demographic profile of the respondents is presented in Table 1. Formal permission was obtained from an authorised representative of the respective institutions. 


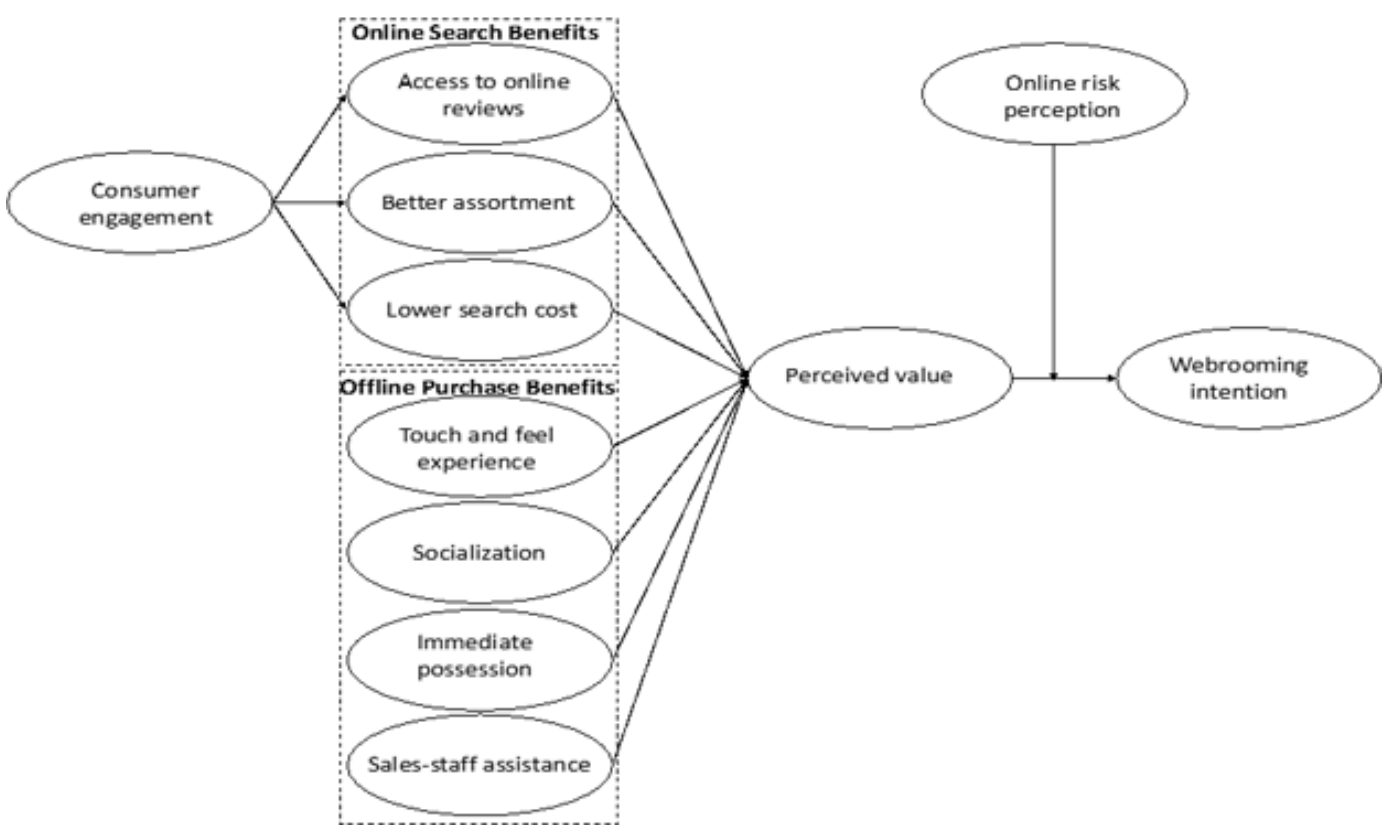

\subsection{Measures and Instrument Development}

The survey instrument was developed from prior validated scales. It had two sections: (1) measures of the present study constructs and (2) respondents' demographic details. All the items were operationalized using a five-point Likert scale ( $1=$ strongly disagree, $5=$ strongly agree). The survey was executed in both English and Hindi languages and the respondents had an option to choose one of those languages as per their language preferences. The Hindi translated version was back translated into English language and cross-examined by two bilingual experts to evaluate the correctness of the translated version of the questionnaire. The instrument was content tested by a panel of experts comprising two Professors of Information Systems and two Senior Marketing Retailers.

A three-item measure for online consumer engagement was obtained from Laroche et al. (2012) and Kharou et al. (2020). A sample item is 'I actively participate in the online activities'. Access to online reviews was measured using a three-item scale proposed by Park and lee (2009). A sample item is 'Online consumer reviews make purchasing easier'. Better assortment was measured on a three-item scale adapted from Emrich et al. (2015). A sample item is 'The assortments offer various price ranges to choose from'. Three items measuring lower search costs were taken from Arora and Sahney (2019). A sample item is 'It does not take much efforts to collect product information online'. Touch and feel experience was measured using three items obtained from Santos and Goncalves (2019). A sample item is 'I would only buy products if I could touch them before purchase'. Three items measuring socialisation were taken from Arora and Sahney (2019). A sample item is 'I go form shopping with my friends or family to socialize'. A three-item measure for immediate possession was used. A sample item is 'I want immediate possession of product after purchasing'. Three items measuring sales-staff assistance were used. A sample item is 'I value the services provided by salesstaff'. Three items measuring webrooming intention were taken from Arora and Sahney (2019). A sample item is 'I am likely to collect information for a product online before buying it offline'.

The perceived value was measured using three items obtained from Voss et al. (2003). A sample item is 'I believe webrooming is an effective practice'. Three items measuring perceived online risks were taken from Chou et al. (2016). A sample item is 'I am concerned about the security of online 
Table 1. Demographic profile of respondents

\begin{tabular}{|c|c|c|}
\hline Category & $\mathbf{N}$ & $\%$ \\
\hline \multicolumn{3}{|l|}{ Gender } \\
\hline Male & 247 & $57.71 \%$ \\
\hline Female & 181 & $42.29 \%$ \\
\hline \multicolumn{3}{|l|}{ Age } \\
\hline $18-30$ years & 134 & $31.31 \%$ \\
\hline $31-45$ years & 165 & $38.55 \%$ \\
\hline 46-60 years & 91 & $21.26 \%$ \\
\hline Above 60 & 38 & $8.88 \%$ \\
\hline \multicolumn{3}{|l|}{ Income (Monthly) } \\
\hline Less than USD 200 & 29 & $6.78 \%$ \\
\hline USD 201-400 & 119 & $27.80 \%$ \\
\hline USD 401-600 & 202 & $47.20 \%$ \\
\hline Above USD 600 & 78 & $18.22 \%$ \\
\hline \multicolumn{3}{|l|}{ Educational Qualification } \\
\hline Secondary or below qualification & 58 & $13.55 \%$ \\
\hline Higher Secondary & 88 & $20.56 \%$ \\
\hline Bachelor's Degree & 189 & $44.16 \%$ \\
\hline Postgraduate Degree or higher & 93 & $21.73 \%$ \\
\hline \multicolumn{3}{|l|}{ Occupation } \\
\hline Unemployed & 54 & $12.62 \%$ \\
\hline Government or semi-government sector & 96 & $22.43 \%$ \\
\hline Private sector & 138 & $32.24 \%$ \\
\hline Self-employment & 98 & $22.90 \%$ \\
\hline Retired & 42 & $9.81 \%$ \\
\hline
\end{tabular}

purchases'. The demographic characteristics of the consumers such as age, gender, and education, may affect the consumer response (Tifferet et al., 2013; Shankar and Jebarajakirthy, 2019). Hence, their effects were controlled.

\subsection{Data Analyses}

Data were preliminarily analysed using t-test to know if there is response bias. Thereafter, Cronbach's alpha values were calculated to examine the internal consistency among the construct items $\left(\alpha^{3} .7\right)$ (Hair et al., 2010). Post that confirmatory factor analysis for the measurement model was done to examine the reliability (composite reliability $(\mathrm{CR})^{3} .7$ ) and convergent validity of the measurement scales. The method prescribed by Fornell and Larcker (1981) was followed to examine discriminant validity (average variance extracted (AVE) ${ }^{3} .5$ and $\mathrm{AVE}^{3}$ inter-construct correlation squares).

Hypotheses were tested at three stages: testing direct effects $\left(\mathbf{H}_{\mathbf{1}}-\mathbf{H}_{\mathbf{1 0}}\right)$, testing mediating effects $\left(\mathbf{H}_{11}\right.$ and $\left.\mathbf{H}_{12}\right)$, and testing moderated-mediation effects $\left(\mathbf{H}_{13}\right.$ and $\left.\mathbf{H}_{14}\right)$. Direct effects were examined by performing structural equation modelling (SEM) in AMOS version 24. PROCESS Macro was used to examine mediation and moderated-mediation effects. 


\section{RESULTS}

\subsection{Preliminary Tests}

The t-test results ( $t=1.68, p=.87$ ) suggested that there is no significant difference between responses and demographic profiles between four cities representing absence of non-response bias (Deutskens et al., 2006). The Cronbach's alpha coefficients of all the constructs under investigation were above 0.7 , representing reliability of the constructs (refer Table 2 ).

In the confirmatory factor analysis (CFA), two items of perceived value were deleted because of low factor loading scores (Hair et al., 2010). Results (refer Table 2) indicated that values of AVE for all study constructs were above 0.5 and CR values were also above the threshold value of 0.7 , indicating the presence of convergent validity. As evident from Table 3, the square root of the AVE values of each construct was found to be higher than the construct's correlation coefficient with other constructs, which indicates the

As responses for both the dependent and independent constructs were collected from the same respondent, Harman one-factor test was done to test for any possibility of common method bias (CMB) as prescribed by Podsakoff et al., (2003). A factor analysis of the eleven main variables represented $73.53 \%$ of the variance, with factor one representing $18.29 \%$ of the variance. Since factor one did not explain the majority of the variance, we can infer that CMB is unlikely to be a concern in the data (Podsakoff et al., 2003).

\subsection{Hypothesis Testing b}

\subsection{Test for Mediation}

The mediation analysis was performed using Model 4 in process macro. Bootstrapped bias-corrected confidence intervals (CIs) was performed for 5,000 re-samples with a 95\% confidence interval to examine the significance of mediation effects (Cheung and Lau, 2008). Results presented in Table 5 indicated that perceived value partially mediated the association between accesses to online reviews, touch and feel experience, immediate possession, socialisation, sales-staff assistance and webrooming intention. However, the association between better assortment, lower search cost, and webrooming intention is fully mediated by perceived value. Hence, H11a, H11b, H11c, H12a, H12b, H12c, and H12d were supported.

\subsection{Test for Moderated-Mediation}

After analysing the mediation effects of social perceived, we examined the moderation effects of online risk perception on these mediation effects (i.e., moderated mediation effects) using the using boot estimates from the 5000 bootstrap samples in the process module (Model 14) (Hayes, 2013). The high and low levels of online risk perception were obtained by adding one standard deviation $(+\mathrm{SD})$ and subtracting one standard deviation (-SD) from the mean value, respectively. The results of moderated mediation analysis are presented in Table 6 . The results indicated that conditional indirect effects of perceived value between better assortment $(\beta=0.0761 ; \mathrm{LLCI}=0.0065$ and ULCI $=$ $0.1412)$, lower search $\operatorname{cost}(\beta=0.0666$; LLCI $=0.0074$ and ULCI $=0.1236)$, touch and feel experience $(\beta=0.05 ; \mathrm{LLCI}=0.0001$ and $\mathrm{ULCI}=0.0971)$, immediate possession $(\beta=0.0984 ; \mathrm{LLCI}=0.016$ and $\mathrm{ULCI}=0.1699)$, socialisation $(\beta=0.0789 ; \mathrm{LLCI}=0.0073$ and $\mathrm{ULCI}=0.1488)$, and webrooming intention vary at high and low levels of online risk perception. Hence H13b, H13c, H14a, H14b, and H14c were supported. However, the mediating effects of perceived value between access to online reviews $(\beta=0.025 ; \mathrm{LLCI}=-0.0072$ and $\mathrm{ULCI}=0.057)$, sales-staff assistance $(\beta=0.066$; LLCI= -0.0016 and $\mathrm{ULCI}=0.1302$ ) and webrooming intention do not vary at high and low levels of online risk perception. Hence, H13a and H14d were not supported. 
Table 2. Summary of the Measurement Model

\begin{tabular}{|c|c|}
\hline Measures and items & FL \\
\hline \multicolumn{2}{|l|}{ Online consumer engagement $(\mathrm{AVE}=0.723, \mathrm{CR}=0.886, \alpha=0.878)$} \\
\hline I am actively participating in the online activities. & 0.88 \\
\hline I enjoyed interacting with the online content. & 0.80 \\
\hline I spent time in exploring different digital platforms & 0.87 \\
\hline \multicolumn{2}{|l|}{ Access to online reviews $(\mathrm{AVE}=0.697, \mathrm{CR}=0.873, \alpha=874)$} \\
\hline Online consumer reviews are useful to me & 0.76 \\
\hline Online consumer reviews make purchasing easier & 0.85 \\
\hline Online consumer reviews make me a smarter shopper & 0.89 \\
\hline \multicolumn{2}{|l|}{ Better assortment $(\mathrm{AVE}=0.742, \mathrm{CR}=0.896, \alpha=0.895)$} \\
\hline The assortments offer various price ranges to choose from. & 0.89 \\
\hline The assortments offer many related products. & 0.91 \\
\hline The assortments offer a variety of different quality ranges to choose from. & 0.78 \\
\hline \multicolumn{2}{|l|}{ Lower search cost $(\mathrm{AVE}=0.652, \mathrm{CR}=0.848, \alpha=0.844)$} \\
\hline It does not take much efforts to collect product information online & 0.79 \\
\hline It does not take much time to collect product information online & 0.86 \\
\hline It is economical to search for information online & 0.77 \\
\hline \multicolumn{2}{|l|}{ Touch and feel experience $(\mathrm{AVE}=0.691, \mathrm{CR}=0.869, \alpha=0.868)$} \\
\hline I feel more comfortable in purchasing a product after physically examining it & 0.71 \\
\hline I would only buy products if I could touch them before purchase & 0.92 \\
\hline I feel more confident making a purchase after touching a product & 0.85 \\
\hline \multicolumn{2}{|l|}{ Sales-staff assistance $(\mathrm{AVE}=0.678, \mathrm{CR}=0.863, \alpha=0.861)$} \\
\hline I value the services provided by sales-staff & 0.84 \\
\hline I find sales-assistance beneficial & 0.82 \\
\hline I make better purchase decisions by taking sales-staff assistance & 0.81 \\
\hline \multicolumn{2}{|l|}{ Socialization $(\mathrm{AVE}=\mathbf{0 . 7 2 6}, \mathrm{CR}=\mathbf{0 . 8 8 8}, \alpha=0.884)$} \\
\hline I miss the experience of interacting with people while shopping online & 0.88 \\
\hline I go form shopping with my friends or family to socialize & 0.91 \\
\hline I enjoy socializing with others when I shop offline & 0.76 \\
\hline \multicolumn{2}{|l|}{ Immediate possession $(\mathrm{AVE}=0.684, \mathrm{CR}=0.866, \alpha=0.867)$} \\
\hline I want immediate possession of product after purchasing & 0.79 \\
\hline When I order a product, I do not want to wait for it to arrive & 0.87 \\
\hline Whenever I purchase a product, I want to use it immediately & 0.82 \\
\hline \multicolumn{2}{|l|}{ Perceived values $(\mathrm{AVE}=0.713, \mathrm{CR}=0.881, \alpha=0.884)$} \\
\hline I believe webrooming is an effective practice & 0.90 \\
\hline Webrooming excites me personally & 0.79 \\
\hline I believe webrooming is a productive practice & 0.84 \\
\hline \multicolumn{2}{|l|}{ Online risk perceptions $(\mathrm{AVE}=0.665, \mathrm{CR}=0.855, \alpha=0.854)$} \\
\hline I am concerned about the security of online purchases & 0.73 \\
\hline I am concerned about the risk of interception of personal and financial information in online purchases & 0.85 \\
\hline I am concerned about the vendor's reputation in online purchases & 0.86 \\
\hline Webrooming intention $(\mathrm{AVE}=0.623, \mathrm{CR}=0.831, \alpha=0.832)$ & \\
\hline
\end{tabular}


Table 2. Continued

\begin{tabular}{|l|l|}
\hline Measures and items & FL \\
\hline I am likely to collect information for a product online before buying it offline & 0.71 \\
\hline It is probable that I will collect information for a product online before buying offline & 0.87 \\
\hline I am certain that I will collect information for a product online before I buy offline & 0.78 \\
\hline Notes: AVE= Average variance extracted, CR= Composite reliability, $\alpha=$ Cronbach's alpha coefficient, FL= Factor loading \\
\hline
\end{tabular}

\section{DISCUSSION}

Due to the advancement of Information Technology and penetration of internet and mobile phones, consumer switch channels during the purchasing process. Hence, consumer channel switching behaviour is one of the crucial issues for retailers. Due to increased engagement over online platforms, consumers tend to search for information online before making a final purchase, and several times consumers show webrooming behaviour by purchasing products offline after searching it online. Hence, marketers are keen to know how online consumer engagement impacts consumers' webrooming intentions. Thus, using a moderated mediation framework, this study attempts to examine how consumer engagement impacts online information search benefits which precede webrooming intention. The results indicate that consumer online engagement significantly impacts better assortment and lower search cost. These results are in accordance with previous findings (Verhoef et al., 2007; Mollen and Wilson, 2010). Hence, consumers who are very active on online know different platforms where they can get relevant information about a specific product and gather information by spending less time and effort compare to offline stores. Further, consumers who

Table 3. Discriminant analysis

\begin{tabular}{|c|c|c|c|c|c|c|c|c|c|c|c|}
\hline Constructs & 1 & 2 & 3 & 4 & 5 & 6 & 7 & 8 & 9 & 10 & 11 \\
\hline $\begin{array}{l}\text { 1. Online consumer } \\
\text { engagement }\end{array}$ & .85 & & & & & & & & & & \\
\hline 2. Lower search cost & .32 & .81 & & & & & & & & & \\
\hline $\begin{array}{l}\text { 3. Access to online } \\
\text { reviews }\end{array}$ & .01 & .15 & .83 & & & & & & & & \\
\hline 4. Better assortment & .56 & .55 & .07 & .86 & & & & & & & \\
\hline 5. Immediate possession & .58 & .56 & .16 & .60 & .80 & & & & & & \\
\hline 6. Socialization & .61 & .58 & .20 & .64 & .66 & .85 & & & & & \\
\hline $\begin{array}{l}\text { 7. Touch and feel } \\
\text { experience }\end{array}$ & .31 & .30 & .31 & .35 & .39 & .38 & .83 & & & & \\
\hline 8. Sales-staff assistance & .42 & .40 & .32 & .41 & .51 & .56 & .53 & .82 & & & \\
\hline 9. Perceived values & .48 & .44 & .32 & .42 & .69 & .69 & .47 & .65 & .84 & & \\
\hline $\begin{array}{l}\text { 10. Online risk } \\
\text { perceptions }\end{array}$ & .24 & .18 & .25 & .25 & .30 & .32 & .66 & .42 & .36 & .82 & \\
\hline $\begin{array}{l}\text { 11. Webrooming } \\
\text { intention }\end{array}$ & .34 & .34 & .44 & .30 & .53 & .53 & .50 & .57 & .68 & .46 & .79 \\
\hline
\end{tabular}


Table 4. The results of the direct effects

\begin{tabular}{|c|c|c|}
\hline Path & $\boldsymbol{\beta}$ & SE \\
\hline Consumer engagement ${ }^{\circledR}$ Access to online reviews & $0.05 \mathrm{~ns}$ & 0.09 \\
\hline Consumer engagement ${ }^{\circledR}$ Better assortment & $0.90 * * *$ & 0.06 \\
\hline Consumer engagement ${ }^{\circledR}$ Lower search cost & $0.87 * * *$ & 0.06 \\
\hline Access to online reviews ${ }^{\circledR}$ Webrooming intention & $0.25 * * *$ & 0.04 \\
\hline Better assortment ${ }^{\circledR}$ Webrooming intention & -0.17 & 0.14 \\
\hline Lower search cost ${ }^{\circledR}$ Webrooming intention & $0.09 \mathrm{~ns}$ & 0.14 \\
\hline Touch and feel experience ${ }^{\circledR}$ Webrooming intention & $0.19 * * *$ & 0.05 \\
\hline Socialization $®$ Webrooming intention & $0.12 *$ & 0.06 \\
\hline Immediate possession $®$ Webrooming intention & $0.15^{* *}$ & 0.06 \\
\hline Sales-staff assistance ${ }^{\circledR}$ Webrooming intention & $0.15^{* *}$ & 0.05 \\
\hline Access to online reviews ${ }^{\circledR}$ Perceived values & $0.13^{* *}$ & 0.04 \\
\hline Better assortment ${ }^{\circledR}$ Perceived values & -0.20 & 0.12 \\
\hline Lower search cost ${ }^{\circledR}$ Perceived values & $0.12 \mathrm{~ns}$ & 0.12 \\
\hline Touch and feel experience ${ }^{\circledR}$ Perceived values & $0.12 * *$ & 0.04 \\
\hline Socialization $®$ Perceived values & $0.39 * * *$ & 0.04 \\
\hline Immediate possession ${ }^{\circledR}$ Perceived values & $0.44 * * *$ & 0.04 \\
\hline Sales-staff assistance ${ }^{\circledR}$ Perceived values & $0.34 * * *$ & 0.04 \\
\hline Perceived values ${ }^{\circledR}$ Webrooming intention & $0.32 * * *$ & 0.08 \\
\hline
\end{tabular}

Notes: ${ }^{* * *} p<0.001 ;{ }^{* *} p<0.01 ;{ }^{*} p<0.05$ Fit indices CMIN/DF $=3.716(p<0.001), \mathrm{CFI}=.88, \mathrm{GFI}=.80, \mathrm{NFI}=.85, \mathrm{TLI}=.86, \mathrm{RMSEA}=.07$. CFI= comparative fit index; GFI= goodness-of-fit index, NFI= normed fit index, TLI= Tucker-Lewis index, RMSEA= root mean square error of approximation.

engage over online platforms also aware of different website where they can find different variety of a specific product. Unexpectedly, results indicated that online engagement does not impact access to online reviews which is contradictory of previous findings (Thakur, 2018; Shankar et al., 2020). As marketers are promoting the consumers reviews at different platforms and easily accessible to all consumers. Hence, to access the online reviews, online engagement is not vital.

The results also indicated that online search benefits (access to online review) and offline purchase benefits (touch and feel experience, immediate socialization possession, and sales-staff assistance) have a significant impact on webrooming intention. The findings are in accordance with previous findings (Flavián et al., 2016, Arora \& Sahney, 2018, 2019; Aw, 2020). Consumers are very susceptive towards product performance and want to confirm the quality of the products before making the final purchase. Online reviews are a trustworthy source of product performance as existing consumers share reviews; hence, consumers tend to access online reviews before making the final purchase. Further, due to perceived risk associated with the online purchase and perceived benefits in offline purchase, consumers show webrooming intention. Consumers receive several offline purchase benefits, including touch and feel the experience, immediate possession, socialization, and sales-staff assistance, which reduce uncertainty and future regret.

Consumers can touch and feel the product in the offline setting and they can reduce the product performance uncertainty. Further, in offline retailing context, consumers can get the ownership of the product as soon they make the payment whereas, consumers cannot get the possession immediately but product delivery take some time. Additionally, during making purchase from offline retailing context, consumers can spent some quality time with family, friends and peers which they cannot 
Table 5. The summary of the mediation effects

\begin{tabular}{|c|c|c|c|c|c|c|}
\hline \multirow[t]{2}{*}{ Hypothesis } & & \multirow[t]{2}{*}{ Effects } & \multirow[t]{2}{*}{ BootSE } & \multicolumn{2}{|c|}{ Bootstrap 95\% CIs } & \multirow[t]{2}{*}{ Mediation } \\
\hline & & & & Lower & Upper & \\
\hline \multirow[t]{2}{*}{ Access to online reviews $®$ PV@WI } & Indirect & 0.139 & 0.024 & 0.0952 & 0.19 & \multirow[t]{2}{*}{ Partial } \\
\hline & Direct & 0.221 & 0.036 & 0.1492 & 0.2925 & \\
\hline \multirow[t]{2}{*}{ Better assortment ${ }^{\circledR} P V ® W I$} & Indirect & 0.331 & 0.053 & 0.2271 & 0.4414 & \multirow[t]{2}{*}{ Full } \\
\hline & Direct & 0.069 & 0.063 & -0.0555 & 0.1943 & \\
\hline \multirow[t]{2}{*}{ Lower search cost $® \mathrm{PV} @ W I$} & Indirect & 0.287 & 0.051 & 0.1867 & 0.3892 & \multirow[t]{2}{*}{ Full } \\
\hline & Direct & 0.096 & 0.058 & -0.0173 & 0.211 & \\
\hline \multirow[t]{2}{*}{ Touch and feel experience ${ }^{\circledR P V ® W I ~}$} & Indirect & 0.202 & 0.027 & 0.1504 & 0.2564 & \multirow[t]{2}{*}{ Partial } \\
\hline & Direct & 0.223 & 0.040 & 0.1436 & 0.3033 & \\
\hline \multirow[t]{2}{*}{ Socialization ${ }^{\circledR P V} ® W I$} & Indirect & 0.311 & 0.047 & 0.2228 & 0.408 & \multirow[t]{2}{*}{ Partial } \\
\hline & Direct & 0.155 & 0.049 & 0.0582 & 0.2533 & \\
\hline \multirow[t]{2}{*}{ Immediate possession ${ }^{\circledR} \mathrm{PV} ® \mathrm{WI}$} & Indirect & 0.352 & 0.049 & 0.2616 & 0.4516 & \multirow[t]{2}{*}{ Partial } \\
\hline & Direct & 0.189 & 0.056 & 0.0782 & 0.3015 & \\
\hline \multirow[t]{2}{*}{ Sales-staff assistance ${ }^{\circledR} \mathrm{PV} ® \mathrm{WI}$} & Indirect & 0.245 & 0.034 & 0.1778 & 0.3151 & \multirow[t]{2}{*}{ Partial } \\
\hline & Direct & 0.251 & 0.044 & 0.1645 & 0.3388 & \\
\hline
\end{tabular}

experience during online purchase hence, tend to webroom. Finally, in case of confusion related to price, variety, attribute, and size, consumers can take the help of sales-staff during the product purchase in offline setting which is not possible during online purchase. Hence, consumer tend to webroom.

Further, perceived value significantly mediate the impact of online search benefits on webrooming intention, which is following previous findings (Kang, 2018). As over online platforms, consumers can access huge amounts of information in a few click, which enhances consumers' perceived value. Similarly, searching for information over online platforms is fun for consumers because they receive interactive rich media over online platforms. Access to consumers' reviews, availability of huge amounts of information in a few click, better assortment, and lower search costs provide utility

Table 6. Results of moderated mediation analysis

\begin{tabular}{|c|c|c|c|c|c|}
\hline \multirow{2}{*}{ Paths } & \multirow{2}{*}{ Effects } & \multirow[b]{2}{*}{ BootSE } & \multicolumn{2}{|c|}{ Bootstrap 95\% CIs } & \multirow[t]{2}{*}{ Hypothesis } \\
\hline & & & Lower & Upper & \\
\hline Access to online reviews $®$ PV $® W I$ & 0.025 & 0.016 & -0.0072 & 0.057 & Not Supported \\
\hline Better assortment $® P V ® W I$ & 0.076 & 0.034 & 0.0065 & 0.1412 & Supported \\
\hline Lower search cost $® P V ® W I$ & 0.066 & 0.029 & 0.0074 & 0.1236 & Supported \\
\hline Touch and feel experience $® P V ® W I$ & 0.050 & 0.024 & 0.0001 & 0.0971 & Supported \\
\hline Socialization $® P V ® W I$ & 0.078 & 0.035 & 0.0073 & 0.1488 & Supported \\
\hline Immediate possession $₫ P V ®$ WI & 0.098 & 0.039 & 0.016 & 0.1699 & Supported \\
\hline 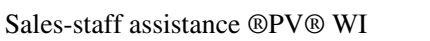 & 0.066 & 0.032 & -0.0016 & 0.1302 & Not Supported \\
\hline
\end{tabular}


to consumers, which motivate them to webrooming. Hence, online search benefits provide several hedonic and utilitarian values to the consumers and they motivate to search information online before making final purchase from offline store.

The association between offline purchase benefits and webrooming intention significantly mediated by perceived value. During offline purchase, consumers receive the product immediately after purchase and receive salespeople's assistance during the purchase, enhancing their perceived utility values. Consumers can also confirm the quality of the product by physically touch it. Further, consumers receive hedonic values during the offline purchase by spending some quality time with family and friends. Hence, perceived hedonic and utilitarian values motivate consumer to purchase the product from retail stores after making online search and consumers tend to webroom.

Finally, the moderated-mediation analysis findings suggest that the mediating impact of perceived value on the association between online search benefits, offline purchase benefits, and webrooming intention vary at high and low levels of consumers' online risk perception. To the best of our knowledge, the existing literature has not examined how the mediating effects of perceived value is moderated by online risk perception. However, studies investigated the impact of online risk perception on webrooming intention (Arora and Sahney, 2018, 2019). Results indicated that consumers with high online risk perception received more perceived value in online information processing and offline purchasing to reduce the uncertainties and perceived risk associated with the online purchase, which leads to webrooming intention. Consumer with high online risk perception are sceptic towards online purchase because they are uncertain about the product performance and try to reduce the purchase guilt hence, they switch the channels to reduce the uncertainty and future guilt and tend to webroom. Whereas, consumers with less online risk perception are not sceptic towards online purchase hence, they complete the journey over online platform only and do not switch the channel during the purchase journey. Hence, consumers show less intent towards webrooming.

\section{THEORETICAL CONTRIBUTIONS}

The study makes several academic contributions to the extant literature. The findings of the study contribute to the newly emerged webrooming concept (Aw, 2020). This study also enriches consumer behaviour, multi-channel retailing, channel switching behaviour, consumer engagement, and CMR theory literature. The study carries several theoretical contribution; first, Consumer webrooming behaviour is a crucial channel switching issue face by marketers, and research on consumer behavioural intention is still in its infancy. Hence, it is warranted to explore the factors affecting consumer webrooming intention. A comprehensive framework rarely exists in the literature exploring webrooming intention. This study proposed a comprehensive moderated mediation framework to conceptual examine the impact of different socio-psychological webrooming intention. Thus, this study contributes to providing a deeper understanding of webrooming intention phenomenon.

Second, Previous literature studies examined the positive impact of consumer engagement on consumer responses, but scant efforts were made to examine the negative impact of consumer engagement on consumer responses. This study enriches the consumer engagement literature by examining how consumer online engagement leads to consumer channel switching intention.

Further, in previous literature, studies examined how different online search benefits and offline purchase benefits motivate consumers to webroom but, as per author knowledge, no study examined the impact of consumer engagement in webrooming context. This study enriches the literature by examining the impact of consumer online engagement on webrooming intention.

Further, consumer perceived value play a crucial role in channel selection during the purchase process. This study examines the mediating effects of perceived value on the association between online search benefits, offline purchase benefits webrooming intention for a better understanding of the phenomenon. Hence, the study also contributes to the perceived value literature. 
Moreover, The moderated-mediation approach was recently introduced in the Information Systems literature to examine the mediating and moderating effects simultaneously between independent and dependent variables (Hayes, 2013). The impact of consumer online engagement on webrooming intention is not straightforward; rather it is a mechanism. Hence, to understand this mechanism, comprehensive framework is required. The complex moderated mediation model has not yet been proposed in the channel switching behaviour literature. Therefore, this study contributes to the channel switching behaviour literature by examining the impact of consumer engagement on webrooming intention by proposing a moderated mediation framework.

Finally, this study also contributes to the CMR theory by applying this theory in the context of channel switching behaviour. Thus, this study has applied CMR theory to a new issue and in a new context. The impact of consumer engagement on webrooming intention is early stages of exploration, and no study has applied CMR theory to examine the impact of consumer engagement with simultaneous effects of mediating and moderating variables on the webrooming intention. This study enriches the CMR literature by proposing a comprehensive moderated mediation model for a better understanding of the webrooming phenomenon.

\section{MANAGERIAL IMPLICATIONS}

This study provides several managerial implications for multi-channel retailers. Retailers tend to adopt multi-channel strategies to enhance their reachability among the consumers. The findings of the study will help multi-channel retailers in designing their channel strategies for gaining competitive advantages. In the current multi-channel retailing scenario, consumer channel switching is one of the crucial challenges retailers are facing, which leads to channel conflict; hence, marketers are keen to know how they can manage consumer channel switching behaviour.

The study findings will help retailers enhance consumers' experience in multi-channel retailing context by managing online consumer engagement. The findings showed that consumer engagement significantly impacts online search benefits, which leads to webrooming intention. Hence, retailers should provide better interactive facilities to consumers over online platforms to complete the purchase journey. Marketers should also map the consumer journey to find the point where consumers left and try to fix those issues.

Results indicated that online search benefits and offline purchase benefits motivate consumers to perform webrooming. Consumers search for information online to save their time and efforts in collecting the information, but, due to perceived online purchasing risk, they tend to purchase products offline. Hence, marketers should ensure a secure and robust system for online purchases to gain consumer trust, so consumers can complete the purchasing process over online platform only. The absence of face-to-face interaction is the major hurdle in purchasing products online; hence, retailers should enhance the interactivity of the website/application to enhance consumer experience over online platforms. Retailers should also develop an online experience section over the website to provide reliable and updated information about product functionality.

Further, consumers do not prefer offline channels to search for the information because it requires time and effort. Hence, retailers should use different sources like electronic display, kiosk to provide detailed information about products at retail stores so consumers can complete the purchasing process. Further, marketers should also offer training the sales-staff about product information so they can help consumers by providing adequate information about products. Retailers should also provide effective customer support by establishing a customer support desk inside the retail stores to handle the customers, quarries. Overall, the study findings suggest the retailers, how they can enhance online purchase and offline search experience to manage consumer channel switching behaviour.

Additionally, to manage the consumers' webrooming intention marketers can either synchronise their channel and deliver product/services using omni-channel delivery system. The integration of the online and offline channel will reduce the negative impact of consumers' webrooming intention. 
Further, marketers can provide different product/services at online and offline channels. For example, if one product is available over online platform, it should not be available at offline channel. Hence, exclusive availability of a product at specific channel will reduce the consumer webrooming intention

Further, the findings suggest that perceived value has a crucial impact on consumer channel choice; hence, marketers should provide purchase values over online platform and information search value over offline stores. Retailers may provide different cashback and promotional offers over online platforms to motivate consumers to purchase products online. In offline retailing stores, retailers can develop experience stores to enhance consumer perceived search values. Finally, results indicated that consumers having high online risk perception tend to webroom to reduce future regret. Hence, marketers should develop a sense of trust in consumer mind by providing a robust and secure system. Retailers should ensure safe and secure transactions over online platforms to reduce channel switching behaviour.

Finally, the findings of the study is not only beneficial to the marketers in providing better consumer experience in multi-retailing context but also provides several suggestions to different stakeholders such as, website/application development team, distribution partner, and delivery partner. Findings suggested that consumer search the product over online platform but due to perceived risk associated with online purchasing, consumers prefer to purchase the products from offline store. Hence, website/application development team should ensure the security of online purchase to reduce the webrooming intention. Further, distribution partner and delivery partner should work together in providing better experience over both online and offline channels by synchronising the channels.

\section{LIMITATIONS AND FUTURE RESEARCH DIRECTIONS}

Despite following probabilistic sampling techniques and rigorous data analyses approach, the present study does have some limitations. For example, it adopted a cross-sectional survey-based research design. For a better generalisation of the results, future researchers may instigate a longitudinal survey.

Our study opens multiple directions for further research. First, in this study, we have used perceived value as mediator. However, other variables such as trust, social values, convenience, and value co-creation play a crucial role in choosing a channel, which can be considered as mediating variables for future studies. Second, future studies can use different moderating variables, such as consumer innovativeness, consumer demographic profile, and product type, for insightful findings.

Finally, it is interesting to see differences in channel switching behaviour based on customer demographic profiles (age, gender, profession, income, and location). In future, a multi-group analysis could be performed between different groups of customers (young and elderly consumers; male and female customers; rural and urban customers), and the results could be compared. 


\section{REFERENCES}

Ahmad, W., \& Sun, J. (2018). Modeling consumer distrust of online hotel reviews. International Journal of Hospitality Management, 71, 77-90. doi:10.1016/j.ijhm.2017.12.005

Ahn, J., \& Back, K. J. (2018). Antecedents and consequences of customer brand engagement in integrated resorts. International Journal of Hospitality Management, 75, 144-152. doi:10.1016/j.ijhm.2018.05.020

Albesa, J. G. (2007). Interaction channel choice in a multichannel environment, an empirical study. International Journal of Bank Marketing, 25(7), 490-506. doi:10.1108/02652320710832630

Arora, S., \& Sahney, S. (2018). Consumer's webrooming conduct: An explanation using the theory of planned behavior. Asia Pacific Journal of Marketing and Logistics, 30(4), 1040-1063. doi:10.1108/APJML-08-2017-0185

Arora, S., \& Sahney, S. (2019). Examining consumers' webrooming behavior: An integrated approach. Marketing Intelligence \& Planning, 37(3), 339-354. doi:10.1108/MIP-05-2018-0152

Aw, E. C. X. (2019). Understanding the webrooming phenomenon. International Journal of Retail \& Distribution Management, 47(10), 1074-1092. doi:10.1108/IJRDM-01-2019-0026

Aw, E. C. X. (2020). Understanding consumers' paths to webrooming: A complexity approach. Journal of Retailing and Consumer Services, 53, 101991. doi:10.1016/j.jretconser.2019.101991

Barbopoulos, I., \& Johansson, L. O. (2016). A multi-dimensional approach to consumer motivation: Exploring economic, hedonic, and normative consumption goals. Journal of Consumer Marketing, 33(1), 75-84. doi:10.1108/JCM-08-2014-1091

Brodie, R. J., Fehrer, J. A., Jaakkola, E., \& Conduit, J. (2019). Actor engagement in networks: Defining the conceptual domain. Journal of Service Research, 22(2), 173-188. doi:10.1177/1094670519827385

Brodie, R. J., Hollebeek, L. D., Jurić, B., \& Ilić, A. (2011). Customer engagement: Conceptual domain, fundamental propositions, and implications for research. Journal of Service Research, 14(3), $252-271$. doi:10.1177/1094670511411703

Carlton, D. W., \& Chevalier, J. A. (2001). Free riding and sales strategies for the Internet. The Journal of Industrial Economics, 49(4), 441-461. doi:10.1111/1467-6451.00157

Carvalho, A., \& Fernandes, T. (2018). Understanding customer brand engagement with virtual social communities: A comprehensive model of drivers, outcomes and moderators. Journal of Marketing Theory and Practice, 26(12), 23-37. doi:10.1080/10696679.2017.1389241

Chahal, H., Wirtz, J., \& Verma, A. (2019). Social media brand engagement: Dimensions, drivers and consequences. Journal of Consumer Marketing, 37(2), 191-204. doi:10.1108/JCM-11-2018-2937

Chen, R., \& He, F. (2003). Examination of brand knowledge, perceived risk and consumers' intention to adopt an online retailer. Total Quality Management \& Business Excellence, 14(6), 677-693. doi:10.1080/1478336032000053825

Cheung, G. W., \& Lau, R. S. (2008). Testing mediation and suppression effects of latent variables: Bootstrapping with structural equation models. Organizational Research Methods, 11(2), 296-325. doi:10.1177/1094428107300343

Chiu, H. C., Hsieh, Y. C., Roan, J., Tseng, K. J., \& Hsieh, J. K. (2011). The challenge for multichannel services: Cross-channel free-riding behavior. Electronic Commerce Research and Applications, 10(2), $268-277$. doi:10.1016/j.elerap.2010.07.002

Chou, S. Y., Shen, G. C., Chiu, H. C., \& Chou, Y. T. (2016). Multichannel service providers' strategy: Understanding customers' switching and free-riding behavior. Journal of Business Research, 69(6), $2226-2232$. doi:10.1016/j.jbusres.2015.12.034

Collier, J. E., Moore, R. S., Horky, A., \& Moore, M. L. (2015). Why the little things matter: Exploring situational influences on customers' self-service technology decisions. Journal of Business Research, 68(3), 703-710. doi:10.1016/j.jbusres.2014.08.001

Cui, G., Lui, H. K., \& Guo, X. (2012). The effect of online consumer reviews on new product sales. International Journal of Electronic Commerce, 17(1), 39-58. doi:10.2753/JEC1086-4415170102 
D'Avanzo, E., \& Pilato, G. (2015). Mining social network users opinions' to aid buyers' shopping decisions. Computers in Human Behavior, 51, 1284-1294. doi:10.1016/j.chb.2014.11.081

Dessart, L., Veloutsou, C., \& Morgan-Thomas, A. (2016). Capturing consumer engagement: Duality, dimensionality and measurement. Journal of Marketing Management, 32(5-6), 399-426. doi:10.1080/026725 7X.2015.1130738

Deutskens, E., De Ruyter, K., \& Wetzels, M. (2006). An assessment of equivalence between online and mail surveys in service research. Journal of Service Research, 8(4), 346-355. doi:10.1177/1094670506286323

Duarte, P., Silva, S. C., \& Ferreira, M. B. (2018). How convenient is it? Delivering online shopping convenience to enhance customer satisfaction and encourage e-WOM. Journal of Retailing and Consumer Services, 44, 161-169. doi:10.1016/j.jretconser.2018.06.007

Emrich, O., Paul, M., \& Rudolph, T. (2015). Shopping benefits of multichannel assortment integration and the moderating role of retailer type. Journal of Retailing, 91(2), 326-342. doi:10.1016/j.jretai.2014.12.003

Fernandes, T., \& Esteves, F. (2016). Customer engagement and loyalty: A comparative study between service contexts. Services Marketing Quarterly, 37(2), 125-139. doi:10.1080/15332969.2016.1154744

Fernández, N. V., Pérez, M. J. S., \& Vázquez-Casielles, R. (2018). Webroomers versus showroomers: Are they the same? Journal of Business Research, 92, 300-320. doi:10.1016/j.jbusres.2018.08.004

Ferreira, M., Zambaldi, F., \& de Sousa Guerra, D. (2020). Consumer engagement in social media: Scale comparison analysis. Journal of Product and Brand Management, 29(4), 491-503. doi:10.1108/JPBM-102018-2095

Flavián, C., Gurrea, R., \& Orús, C. (2016). Choice confidence in the webrooming purchase process: The impact of online positive reviews and the motivation to touch. Journal of Consumer Behaviour, 15(5), 459-476. doi:10.1002/cb.1585

Flavián, C., Gurrea, R., \& Orús, C. (2020). Combining channels to make smart purchases: The role of webrooming and showrooming. Journal of Retailing and Consumer Services, 52, 101923. doi:10.1016/j.jretconser.2019.101923

Fornell, C., \& Larcker, D. F. (1981). Evaluating structural equation models with unobservable variables and measurement error. JMR, Journal of Marketing Research, 18(1), 39-50. doi:10.1177/002224378101800104

Forsythe, S., Liu, C., Shannon, D., \& Gardner, L. C. (2006). Development of a scale to measure the perceived benefits and risks of online shopping. Journal of Interactive Marketing, 20(2), 55-75. doi:10.1002/dir.20061

Frasquet, M., Ruiz-Molina, M. E., \& Molla-Descals, A. (2015). The role of the brand in driving online loyalty for multichannel retailers. International Review of Retail, Distribution and Consumer Research, 25(5), 490-502. doi:10.1080/09593969.2015.1081100

Gensler, S., Verhoef, P. C., \& Böhm, M. (2012). Understanding consumers' multichannel choices across the different stages of the buying process. Marketing Letters, 23(4), 987-1003. doi:10.1007/s11002-012-9199-9

Gong, T. (2018). Customer brand engagement behavior in online brand communities. Journal of Services Marketing, 32(3), 286-299. doi:10.1108/JSM-08-2016-0293

Goraya, M. A. S., Zhu, J., Akram, M. S., Shareef, M. A., Malik, A., \& Bhatti, Z. A. (2020). The impact of channel integration on consumers' channel preferences: Do showrooming and webrooming behaviors matter? Journal of Retailing and Consumer Services, 102130. doi:10.1016/j.jretconser.2020.102130

Goworek, H., \& McGoldrick, P. (2015). Retail marketing management: Principles and practice. Pearson Higher Education.

Ha, S., \& Stoel, L. (2009). Consumer e-shopping acceptance: Antecedents in a technology acceptance model. Journal of Business Research, 62(5), 565-571. doi:10.1016/j.jbusres.2008.06.016

Haas, A., \& Kenning, P. (2014). Utilitarian and hedonic motivators of shoppers' decision to consult with salespeople. Journal of Retailing, 90(3), 428-441. doi:10.1016/j.jretai.2014.05.003

Hair, J. F., Black, W. C., Babin, B. J., \& Anderson, R. E. (2010). Multivariate Data Analysis (7th ed.). Prentice Hall. 
Harmeling, C. M., Moffett, J. W., Arnold, M. J., \& Carlson, B. D. (2017). Toward a theory of customer engagement marketing. Journal of the Academy of Marketing Science, 45(3), 312-335. doi:10.1007/s11747-016-0509-2

Hayes, A. F. (2013). Methodology in the social sciences. Introduction to mediation, moderation, and conditional process analysis: A regression-based approach. Guilford Press.

Heitz-Spahn, S. (2013). Cross-channel free-riding consumer behavior in a multichannel environment: An investigation of shopping motives, sociodemographics and product categories. Journal of Retailing and Consumer Services, 20(6), 570-578. doi:10.1016/j.jretconser.2013.07.006

Hennig-Thurau, T., Gwinner, K. P., Walsh, G., \& Gremler, D. D. (2004). Electronic word-of-mouth via consumeropinion platforms: What motivates consumers to articulate themselves on the internet? Journal of Interactive Marketing, 18(1), 38-52. doi:10.1002/dir.10073

Hollebeek, L. D., Srivastava, R. K., \& Chen, T. (2019). SD logic-informed customer engagement: Integrative framework, revised fundamental propositions, and application to CRM. Journal of the Academy of Marketing Science, 47(1), 161-185. doi:10.1007/s11747-016-0494-5

Islam, H., Jebarajakirthy, C., \& Shankar, A. (2019). An experimental based investigation into the effects of website interactivity on customer behavior in online purchase context. Journal of Strategic Marketing, 1-24. doi:10.1080/0965254X.2019.1637923

Jebarajakirthy, C., \& Shankar, A. (2020). Impact of online convenience on mobile banking adoption intention: A moderated mediation approach. Journal of Retailing and Consumer Services, 58, 102323. doi:10.1016/j. jretconser.2020.102323

Jebarajakirthy, C., Yadav, R., \& Shankar, A. (2020). Insights for luxury retailers to reach customers globally. Marketing Intelligence \& Planning, 38(7), 797-811. doi:10.1108/MIP-10-2019-0493

Jepsen, A. L. (2007). Factors affecting consumer use of the Internet for information search. Journal of Interactive Marketing, 21(3), 21-34. doi:10.1002/dir.20083

Jiang, L. A., Yang, Z., \& Jun, M. (2013). Measuring consumer perceptions of online shopping convenience. Journal of Service Management, 24(2), 191-214. doi:10.1108/09564231311323962

Kacen, J. J., Hess, J. D., \& Chiang, W. Y. K. (2013). Bricks or clicks? Consumer attitudes toward traditional stores and online stores. Global Economics and Management Review, 18(1), 12-21. doi:10.1016/S23401540(13)70003-3

Kalyanam, K., \& Tsay, A. A. (2013). Free riding and conflict in hybrid shopping environments: Implications for retailers, manufacturers, and regulators. The Antitrust Bulletin, 58(1), 19-68. doi:10.1177/0003603X1305800102

Kang, J. Y. M. (2018). Showrooming, webrooming, and user-generated content creation in the omnichannel era. Journal of Internet Commerce, 17(2), 145-169. doi:10.1080/15332861.2018.1433907

Kharouf, H., Biscaia, R., Garcia-Perez, A., \& Hickman, E. (2020). Understanding online event experience: The importance of communication, engagement and interaction. Journal of Business Research, 121, 735-746. Advance online publication. doi:10.1016/j.jbusres.2019.12.037

Kim, C., Zhao, W., \& Yang, K. H. (2008). An empirical study on the integrated framework of e-CRM in online shopping: Evaluating the relationships among perceived value, satisfaction, and trust based on customers' perspectives. Journal of Electronic Commerce in Organizations, 6(3), 1-19. doi:10.4018/jeco.2008070101

Kumar, J., \& Kumar, V. (2020). Drivers of brand community engagement. Journal of Retailing and Consumer Services, 54, 101949. doi:10.1016/j.jretconser.2019.101949

Kumar, V., \& Pansari, A. (2016). Competitive advantage through engagement. JMR, Journal of Marketing Research, 53(4), 497-514. doi:10.1509/jmr.15.0044

Laroche, M., Habibi, M. R., Richard, M. O., \& Sankaranarayanan, R. (2012). The effects of social media based brand communities on brand community markers, value creation practices, brand trust and brand loyalty. Computers in Human Behavior, 28(5), 1755-1767. doi:10.1016/j.chb.2012.04.016

Lazarus, R. S. (1991). Progress on a cognitive-motivational-relational theory of emotion. The American Psychologist, 46(8), 819-834. doi:10.1037/0003-066X.46.8.819 PMID:1928936 
Lee, C. K., Yoon, Y. S., \& Lee, S. K. (2007). Investigating the relationships among perceived value, satisfaction, and recommendations: The case of the Korean DMZ. Tourism Management, 28(1), 204-214. doi:10.1016/j. tourman.2005.12.017

Lee, H. H., \& Ma, Y. J. (2012). Consumer perceptions of online consumer product and service reviews. Journal of Research in Interactive Marketing, 6(2), 110-132. doi:10.1108/17505931211265426

Lee, M. Y., Kim, Y. K., \& Fairhurst, A. (2009). Shopping value in online auctions: Their antecedents and outcomes. Journal of Retailing and Consumer Services, 16(1), 75-82. doi:10.1016/j.jretconser.2008.11.003

Li, L. P., Juric, B., \& Brodie, R. J. (2017). Dynamic multi-actor engagement in networks: The case of United Breaks Guitars. Journal of Service Theory and Practice, 27(4), 738-760. doi:10.1108/JSTP-04-2016-0066

Lin, M., Prabhala, N. R., \& Viswanathan, S. (2009). Can social networks help mitigate information asymmetry in online markets? ICIS 2009 Proceedings, 202.

Maheswarappa, S. S., Sivakumaran, B., \& Kumar, A. G. (2017). Returns to search when consumers use and do not use recommendation agents. Asia Pacific Journal of Marketing and Logistics, 29(4), 813-836. doi:10.1108/ APJML-10-2016-0188

Marino, V., \& Presti, L. L. (2018). Engagement, satisfaction and customer behavior-based CRM performance. Journal of Service Theory and Practice, 28(5), 682-707. doi:10.1108/JSTP-11-2017-0222

Mazaheri, E., Richard, M. O., \& Laroche, M. (2010). Investigating the moderating impact of hedonism on online consumer behavior. Journal of Global Academy of Marketing Science, 20(2), 123-134. doi:10.1080/12 297119.2010.9730185

Mehra, A., Kumar, S., \& Raju, J. S. (2013). Showrooming' and the competition between store and online retailers. Available at: http://citeseerx.ist.psu.edu/viewdoc/download?doi=10.1.1.467.1278\&rep=rep1\&type=pdf

Meshram, K., \& O'Cass, A. (2018). Senior citizens' perspective on the value offerings of third place via customer to customer (C-2-C) engagement. Journal of Services Marketing, 32(2), 175-194. doi:10.1108/JSM-08-2014-0269

Morgan-Thomas, A., Dessart, L., \& Veloutsou, C. (2020). Digital ecosystem and consumer engagement: A sociotechnical perspective. Journal of Business Research, 121, 713-723. Advance online publication. doi:10.1016/j. jbusres.2020.03.042

Ng, S. C., Sweeney, J. C., \& Plewa, C. (2020). Customer engagement: A systematic review and future research priorities. Australasian Marketing Journal, 28(4), 235-252. Advance online publication. doi:10.1016/j. ausmj.2020.05.004

Nicholls, A. R., Polman, R. C., \& Levy, A. R. (2012). A path analysis of stress appraisals, emotions, coping, and performance satisfaction among athletes. Psychology of Sport and Exercise, 13(3), 263-270. doi:10.1016/j. psychsport.2011.12.003

Noble, S. M., Griffith, D. A., \& Weinberger, M. G. (2005). Consumer derived utilitarian value and channel utilization in a multi-channel retail context. Journal of Business Research, 58(12), 1643-1651. doi:10.1016/j. jbusres.2004.10.005

Park, C., \& Lee, T. M. (2009). Antecedents of online reviews' usage and purchase influence: An empirical comparison of US and Korean consumers. Journal of Interactive Marketing, 23(4), 332-340. doi:10.1016/j. intmar.2009.07.001

Park, E. J., Kim, E. Y., Funches, V. M., \& Foxx, W. (2012). Apparel product attributes, web browsing, and e-impulse buying on shopping websites. Journal of Business Research, 65(11), 1583-1589. doi:10.1016/j. jbusres.2011.02.043

Peck, J., \& Childers, T. L. (2006). If I touch it I have to have it: Individual and environmental influences on impulse purchasing. Journal of Business Research, 59(6), 765-769. doi:10.1016/j.jbusres.2006.01.014

Podsakoff, P. M., MacKenzie, S. B., Lee, J. Y., \& Podsakoff, N. P. (2003). Common method biases in behavioral research: A critical review of the literature and recommended remedies. The Journal of Applied Psychology, 88(5), 879-903. doi:10.1037/0021-9010.88.5.879 PMID:14516251 
PwC's Annual Global Total Retail Consumer Survey. (2015). Total Retail 2015: retailers and the age of disruption. Available at: www.pwc.com/gx/en/retail-consumer/retail-consumer-publications/global-multi-channel-consumersurvey/assets/pdf/total-retail-2015.pdf

Rohm, A. J., \& Swaminathan, V. (2004). A typology of online shoppers based on shopping motivations. Journal of Business Research, 57(7), 748-757. doi:10.1016/S0148-2963(02)00351-X

Rubio, N., Villaseñor, N., \& Yagüe, M. J. (2017). Creation of consumer loyalty and trust in the retailer through store brands: The moderating effect of choice of store brand name. Journal of Retailing and Consumer Services, 34, 358-368. doi:10.1016/j.jretconser.2016.07.014

Santos, S., \& Gonçalves, H. M. (2019). Multichannel consumer behaviors in the mobile environment: Using fsQCA and discriminant analysis to understand webrooming motivations. Journal of Business Research, 101, 757-766. doi:10.1016/j.jbusres.2018.12.069

Shankar, A., \& Datta, B. (2018). Factors affecting mobile payment adoption intention: An Indian perspective. Global Business Review, 19(3, suppl), S72-S89. doi:10.1177/0972150918757870

Shankar, A., \& Datta, B. (2019). Measuring Mobile Commerce Service Quality: A Review of Literature. M-Commerce: Experiencing the Phygital Retail, 319.

Shankar, A., Datta, B., \& Jebarajakirthy, C. (2019). Are the generic scales enough to measure service quality of mobile banking? A comparative analysis of generic service quality measurement scales to mobile banking context. Services Marketing Quarterly, 40(3), 224-244. doi:10.1080/15332969.2019.1630176

Shankar, A., Datta, B., Jebarajakirthy, C., \& Mukherjee, S. (2020a). Exploring Mobile Banking Service Quality: A Qualitative Approach. Services Marketing Quarterly, 41(2), 1-23. doi:10.1080/15332969.2020.1742982

Shankar, A., \& Jain, S. (2020). Factors affecting luxury consumers' webrooming intention: A moderated-mediation approach. Journal of Retailing and Consumer Services, 58, 102306. doi:10.1016/j.jretconser.2020.102306

Shankar, A., \& Jebarajakirthy, C. (2019). The influence of e-banking service quality on customer loyalty. International Journal of Bank Marketing, 37(5), 1119-1142. doi:10.1108/IJBM-03-2018-0063

Shankar, A., Jebarajakirthy, C., \& Ashaduzzaman, M. (2020). How do electronic word of mouth practices contribute to mobile banking adoption? Journal of Retailing and Consumer Services, 52, 101920. doi:10.1016/j. jretconser.2019.101920

Shankar, A., \& Kumari, P. (2016). Factors affecting mobile banking adoption behavior in India. Journal of Internet Banking and Commerce, 21(1), 1-24.

Shankar, A., \& Rishi, B. (2020). Does convenience matter in mobile banking adoption intention? Australasian Marketing Journal, 28(4), 273-285. Advance online publication. doi:10.1016/j.ausmj.2020.06.008

Smith, D. N., \& Sivakumar, K. (2004). Flow and Internet shopping behavior: A conceptual model and research propositions. Journal of Business Research, 57(10), 1199-1208. doi:10.1016/S0148-2963(02)00330-2

Thakur, R. (2018). Customer engagement and online reviews. Journal of Retailing and Consumer Services, 41, 48-59. doi:10.1016/j.jretconser.2017.11.002

Tifferet, S., Shani, N., \& Cohen, H. (2013). Gender differences in the status consumption of coffee. Human Ethology Bulletin, 28(3), 5-9.

Verhoef, P. C., Kannan, P. K., \& Inman, J. J. (2015). From multi-channel retailing to omni-channel retailing: Introduction to the special issue on multi-channel retailing. Journal of Retailing, 91(2), 174-181. doi:10.1016/j. jretai.2015.02.005

Verhoef, P. C., Neslin, S. A., \& Vroomen, B. (2007). Multichannel customer management: Understanding the research-shopper phenomenon. International Journal of Research in Marketing, 24(2), 129-148. doi:10.1016/j. ijresmar.2006.11.002

Verleye, K., Gemmel, P., \& Rangarajan, D. (2014). Managing engagement behaviors in a network of customers and stakeholders: Evidence from the nursing home sector. Journal of Service Research, 17(1), 68-84. doi:10.1177/1094670513494015 
Voss, K. E., Spangenberg, E. R., \& Grohmann, B. (2003). Measuring the hedonic and utilitarian dimensions of consumer attitude. JMR, Journal of Marketing Research, 40(3), 310-320. doi:10.1509/jmkr.40.3.310.19238

Wang, J., Yang, Z., \& Brocato, E. D. (2018). An investigation into the antecedents of prepurchase online search. Information \& Management, 55(3), 285-293. doi:10.1016/j.im.2017.08.001

Wang, T., \& Lee, F. Y. (2020). Examining customer engagement and brand intimacy in social media context. Journal of Retailing and Consumer Services, 54, 102035. doi:10.1016/j.jretconser.2020.102035

Wang, Y. M., Lin, H. H., Tai, W. C., \& Fan, Y. L. (2016). Understanding multi-channel research shoppers: An analysis of Internet and physical channels. Information Systems and e-Business Management, 14(2), 389-413. doi:10.1007/s10257-015-0288-1

Wirtz, J., den Ambtman, A., Bloemer, J., Horváth, C., Ramaseshan, B., van de Klundert, J., \& Kandampully, J. (2013). Managing brands and customer engagement in online brand communities. Journal of Service Management, 24(3), 223-244. doi:10.1108/09564231311326978

Wong, R. M. M., Wong, S. C., \& Ke, G. N. (2018). Exploring online and offline shopping motivational values in Malaysia. Asia Pacific Journal of Marketing and Logistics, 30(2), 352-369. doi:10.1108/APJML-10-2016-0197

Woodside, A. G. (2013). Moving beyond multiple regression analysis to algorithms: Calling for adoption of a paradigm shift from symmetric to asymmetric thinking in data analysis and crafting theory. Journal of Business Research, 66(4), 463-472. doi:10.1016/j.jbusres.2012.12.021

Yuan, D., Lin, Z., Filieri, R., Liu, R., \& Zheng, M. (2020). Managing the product-harm crisis in the digital era: The role of consumer online brand community engagement. Journal of Business Research, 115, 38-47. doi:10.1016/j.jbusres.2020.04.044

Zhang, K. Z., Cheung, C. M., \& Lee, M. K. (2014). Examining the moderating effect of inconsistent reviews and its gender differences on consumers' online shopping decision. International Journal of Information Management, 34(2), 89-98. doi:10.1016/j.jinfomgt.2013.12.001

Amit Shankar (PhD) is an Assistant Professor in Marketing in the Indian Institute of Management Visakhapatnam, India. His research interests are in the areas of service quality, services marketing and mobile banking. Amit's research has been published in the Journal of Retailing and Consumer Services, Journal of Marketing Management, Marketing Intelligence \& Planning, Journal of Strategic Marketing, Journal of Nonprofit \& Public Sector Marketing, Services Marketing Quarterly, International Journal of Bank Marketing, Journal of Internet Banking and Commerce, Global Business Review, and International Journal of Service Technology and Management among others.

Rambalak Yadav is an Assistant Professor in the Department of Marketing at Institute of Management Technology, Hyderabad, India. He is a PhD from Indian Institute of Technology (ISM) Dhanbad in the area of green consumption behavior. Rambalak is a recipient of Junior Research Fellowship and National Eligibility Test certificate awarded by University Grants Commission, Government of India. In the past he has edited special issues in Journal of Strategic Marketing (ABDC- A category) and International Journal of Nonprofit and Voluntary Sector Marketing (ABDC- $B$ category).

Manish Gupta is Assistant Professor in the Department of HR at IBS Hyderabad, IFHE (Deemed to be University). His PhD thesis is in the area of 'work engagement'. Manish is a recipient of Junior Research Fellowship and National Eligibility Test certificate awarded by University Grants Commission, Government of India. He is Editorial Team Member of Australasian Journal of Information Systems. He is a member of ISDS, AIMA, DSI, and IBSAF. Currently, he is authoring a book for Sage. He is editing two books with IGI Global, USA, and one with Apple Academic Press Inc., a member of the Taylor \& Francis Group, USA. He is also editing Special Issues for Human Resource Management Review, Australasian Journal of Information Systems, International Journal of Knowledge Management, Advances in Developing Human Resources (Sage), Journal of Global Operations and Strategic Sourcing (Emerald), and industrial and Commercial Training (Emerald). His teaching areas include Human Resource Management, Entrepreneurship, and Organizational Behavior, among others. His scholastic work is available at https://scholar.google.co.in/citations?user=yJtwSkwAAAAJ\&hl=en.

Charles Jebarajakirthy is a Lecturer in Marketing in Griffith Business School, Gold Coast, Australia. His research interests are in the areas of retailing, consumer behaviour and services marketing. Charles's research has been published in the International Journal of Hospitality Management, Journal of Retailing and Consumer Services, Marketing Intelligence \& Planning, Journal of Strategic Marketing, Asia Pacific Journal of Marketing and Logistics, International Journal of Consumer Studies, Journal of Young Consumers, International Journal of Nonprofit and Voluntary Sector Marketing, and International Journal of Bank Marketing among others. 